\title{
MENINGKATKAN KEMAMPUAN GURU DALAM MEMBUAT PROPOSAL PENELITIAN TINDAKAN KELAS PADA MTS BINAAN MELALUI WORKSHOP
}

\author{
Prihatini Hidayati \\ Pengawas Madrasah Kementerian Agama Kota Jakarta Selatan \\ Email : prie.tea01@gmail.com Hp : 081219378899
}

\begin{abstract}
This research aims to describe the process of creating Class Action Research proposal through a workshop, and also to improve teacher skill of creating Class Action Research through a workshop in Jakarta. Furthermore, the objective of this research is to describe the respond of teacher towards activities performed. This research is classified as supervisory action research by involving 25 teacher. The research has done with two cycle and each cycle contained of four stages: planning, execution, observation and reflexion. Indicator of performance that have been set is if there are at least $80 \%$ teacher classified to very good and good in aspect of assessing Class Action Research, then it can be said that the action is successful. Measured aspect in assessing successful of this action is the readiness of teacher following the workshop and score of workshop execution. From the result, obtained that there are increases of teacher skill in creating Class Action Research from cycle 1 until cycle 2. Therefore, it can be concluded that workshop can increase teacher skill in creating Class Action Research proposal at MTs in Jakarta. Therefore, it can be suggested that workshop can be used as an alternative to increase teacher skill in creating Class Action Research.
\end{abstract}

Keyword : Teacher skill, Class Action Research proposal, workshop.

\begin{abstract}
ABSTRAK
Penelitian ini bertujuan untuk mendeskripsikan proses membuat proposal Penelitian Tindakan Kelas melalui workshop, serta meningkatkan kemampuan guru dalam membuat proposal Penelitian Tindakan Kelas melalui workshop pada binaan pengawas di Jakarta. Selain itu, penelitian ini juga bertujuan untuk mendeskripsikan respon guru terhadap kegiatan yang dilakukan. Penelitian ini tergolong penelitian tindakan kepengawasan dengan melibatkan 25 orang guru. Penelitian dilakukan dengan dua siklus dan masing-masing siklus terdiri atas empat tahapan, yakni: perencanaan, pelaksanaan, observasi dan refleksi. Indikator kinerja yang ditetapkan adalah: bila minimal terdapat $80 \%$ guru tergolong sangat baik dan baik dalam aspek penilaian peneltian tindakan kelas, maka sudah dapat dikatakan tindakan yang diterapkan berhasil. Aspek yang diukur dalam menilai keberhasilan tindakan adalah kesiapan guru mengikuti workshop dan hasil pelaksanaan workshop. Dari hasil analisis diperoleh bahwa terjadi peningkatan kesiapan kemampuan guru dalam membuat proposal penelitian tindakan dari siklus I ke siklus II. Ketercapaian indikator kinerja terdapat pada tindakan ke II. Dengan demikian dapat
\end{abstract}


disimpulkan bahwa melalui workshop dapat meningkatkan kemampuan guru dalam membuat proposal penelitian tindakan kelas pada MTs binaan di Jakarta. Dengan demikian dapat disarankan kepada pengawas atau peneliti yang lain bahwa kegiatan workshop dapat dipakai sebagai salah satu alternatif dalam meningkatkan kemampuan guru dalam membuat penelitian tindakan kelas.

\section{Kata Kunci : Kemampuan guru, proposal penelitian tindakan kelas, workshop.}

\section{PENDAHULUAN}

Kebijakan pemerintah di bidang pendidikan telah bergulir dengan ditetapkannya Peraturan Menteri Negara Pendayagunaan Aparatur Negara dan Reformasi Birokrasi no. 16 tahun 2009 tentang Jabatan Fungsional Guru dan Angka Kreditnya. Menimbang bahwa Keputusan Menteri Negara Pendayagunaan Aparatur Negara Nomor 84/1993 tentang Jabatan Fungsional Guru dan Angka Kreditnya sudah tidak sesuai dengan perkembangan profesi dan tuntutan kompetensi Guru. Sehubungan dengan hal tersebut perlu mengatur kembali Jabatan Fungsional Guru dan Angka Kreditnya. Dalam Permenpan Reformasi Birokrasi tersebut dijelaskan bahwa untuk memenuhi kenaikan pangkat tugas guru selain mendidik, mengajar, membimbing, mengarahkan, melatih, menilai dan mengevaluasi peserta didik, Guru juga wajib melaksanakan Pengembangan Keprofesian Berkelanjutan (PKB). Pengembangan Keprofesian Berkelanjutan (PKB) terdiri dari Pengembangan Diri dan Penulisan Karya Tulis Ilmiah/ Karya Inovatif. Namun pada pelaksanaan kegiatan supervisi di Madrasah Binaan (KKM 3) Jakarta, pengawas mendapat satu temuan permasalahan yakni ada diantara guru untuk mengurus kenaikan pangkat kendalanya adalah guru-guru kesulitan dan bahkan ada yang tidak mampu membuat Karya Tulis Ilmiah khususnya dalam hal Penelitian Tindakan Kelas (PTK).

Saat ini pengawas sekolah dituntut untuk memiliki kompetensi penelitian pengembangan, yang tidak cukup dianggap hanya sekedar penerima pembaharuan dari hasil penelitian para peneliti dari kalangan perguruan tinggi, melainkan ikut bertanggung jawab serta dan berperan aktif dalam mengembangkan pengetahuan dan keterampilannya sendiri melalui penelitian 
tindakan sekolah yang berkaitan dengan tugas pokok pengawas sekolah yaitu memantau, menilai, membina dan melaporkan serta melaksanakan tindak lanjut hasil kepengawasan.

Berdasarkan hasil temuan dan sesuai dengan tugas pokok pengawas maka peneliti mengambil permasalahan penelitian dengan judul 'Meningkatkan Kemampuan Guru dalam Membuat Proposal Penelitian Tindakan Kelas (PTK) pada MTs Binaan Melalui Workshop'.

Berdasarkan latar belakang, rumusan masalah yang timbul adalah bagaimana proses pelaksanaan workshop dalam kaitannya dengan kemampuan guru pada MTs binaan peneliti di Jakarta dalam membuat proposal penelitian tindakan kelas; dan bagaimana melalui workshop dapat meningkatkan kemampuan guru MTs binaan peneliti di Jakata dalam membuat proposal penelitian tindakan kelas. Tujuan penelitian adalah untuk mendeskripsikan proses pelaksanaan workshop dalam kaitannya dengan kemampuan guru MTs Binaan dalam membuat proposal penelitian tindakan kelas di Jakarta melalui workshop; dan untuk meningkatkan kemampuan guru dalam membuat proposal penelitian tindakan kelas pada MTs binaan peneliti di Jakarta.

Menurut Departemen Pendidikan dan Kebudayaan (Depdikbud) istilah kemampuan mempunyai banyak makna yang kesemuanya menunjuk kepada kemampuan melaksanakan sesuatu yang diperoleh melalui pendidikan dan latihan. Dalam hubungan dengan tenaga kependidikan kompetensi menunjuk kepada perbuatan (performance) yang bersifat rasional dan memenuhi spesifikasi tertentu di dalam pelaksanaan tugas-tugas kependidikan. Menurut Houston dan Howson, kemampuan (competency) diartikan sebagai tugas yang memadai atau pemilikan pengetahuan, keterampilan dalam kemampuan yang dituntut oleh jabatan guru/dosen. Dekker mengatakan kemampuan guru merupakan kemampuan profesional yang berhubungan dengan jabatan guru.

Menurut Sugiono (2013) proposal penelitian adalah pedoman yang berisikan berbagai kegiatan serta langkah-langkah sistematis yang akan diikuti oleh seorang peneliti dalam melaksanakan suatu penelitian. Menurut Prof. Robertus Wahyudi Triweko, Ph.d pengertian proposal penelitian adalah suatu bentuk pedoman rencana kerja yang terdiri atas semua unsurunsur pokok dalam proses penelitian. Proposal penelitian juga harus berisi informasi yang cukup bagi si pembaca untuk mengevaluasi penelitian yang diajukan. Secara umum, pengertian proposal penelitian adalah jenis proposal yang banyak digunakan untuk bidang akademik khususnya dalam bidang karya ilmiah.

Penelitian Tindakan Kelas (PTK) adalah suatu kegiatan penelitian ilmiah yang dilakukan secara rasional, sistematis dan empiris reflektif terhadap berbagai tindakan yang dilakukan oleh guru atau dosen (tenaga pendidik), kolaborasi (tim peneliti) yang sekaligus sebagai peneliti, 
sejak disusunnya suatu perencanaan sampai penilaian terhadap tindakan nyata di dalam kelas yang berupa kegiatan belajar mengajar, untuk memperbaiki dan meningkatkan kondisi pembelajaran yang dilakukan (Iskandar, 2012). Selain itu Penelitian Tindakan Kelas (PTK) juga merupakan bagian dari penelitian masalah praktis yang memiliki tujuan utama untuk memperbaiki proses dan hasil pembelajaran pendidikan jasmani atau memperbaiki kualitas proses dan hasil kepelatihan olahraga (Kristiyanto, 2010).

Workshop adalah suatu pertemuan ilmiah dalam bidang sejenis (pendidikan) untuk menghasilkan karya nyata (Badudu, 1988). Lebih lanjut, Harbinson mengemukakan bahwa pendidikan dan pelatihan secara umum diartikan sebagai proses pemerolehan keterampilan dan pengetahuan yang terjadi di luar sistem persekolahan, yang sifatnya lebih heterogen dan kurang terbakukan dan tidak berkaitan satu dengan lainnya, karena memiliki tujuan yang berbeda (Harbinson, 1973).

\section{METODE}

Penelitian ini menggunakan pendekatan campuran kuantitatif dan kualitatif. Pendekatan kuantitatif menggunakan jenis Penelitian Tindakan dengan dua siklus. Teknik analisis data kuantitatif yang digunakan dalam penelitian ini adalah teknik analisis deskriptif komparatif yaitu membandingkan kompetensi guru dalam membuat proposal PTK dari kondisi awal, setelah siklus I dan setelah siklus II. Waktu, tempat, dan subjek penelitian. Waktu Penelitian ini dilaksanakan pada semester 1 tahun ajaran 2017/2018, tepatnya dilaksanakan selama empat bulan yaitu mulai dari bulan Juni hingga Oktober tahun 2017. Bulan pertama yaitu bulan Juni peneliti gunakan untuk menyusun rencana penelitian. Setelah itu peneliti merencanakan instrument penelitian dan memperbaiki rencana penelitian pada bulan kedua atau bulan Juli. Setelah rencana penelitian dan instrumen penelitian telah siap, peneliti melakukan Penelitian Tindakan Sekolah (PTS) mulai 18 Agustus hingga 24 September 2017. Setelah itu peneliti melakukan analisa data, seminar laporan hasil penelitaan. diskusi dengan guru binaan dan teman sejawat serta menyusun laporan penelitian pada bulan Oktober 2017.

Tempat penelitian ini sesuai tempat tugas peneliti di MTs Binaan (KKMTs 3) yang terdiri dari 7 MTs yang tergabung dalam KKMTs 3 yaitu MTs Al Falah, MTs Al Ikhlas, MTs Miftahul Falah, MTs Nurussalam, MTs As Syirath, MTs Pembangunan dan MTsN 3 Jakarta. Sedangkan yang bersedia untuk menjadi tuan rumah dalam pelaksanaan workshop adalah MTs Al Falah. Subjek dalam penelitian ini adalah guru binaan (KKMTs 3) Jakarta sejumlah 25 orang guru. Narasumber pada penelitian ini adalah Dr. Juanda Kasim, M.Si dari Balai Diklat Kementerian 
Agama Provinsi DKI Jakarta. Indikator dalam penelitian ini adalah $80 \%$ guru dapat membuat Proposal Tindakan Kelas (PTK) sesuai dengan sistematika yang sudah ditetapkan.

\section{TAHAPAN DAN JALANNYA PENELITIAN}

Penelitian ini merupakan proses pengkajian sistem berdaur sebagaimana kerangka berpikir yang dikembangkan oleh Suharsimi Arikunto dkk. Prosedur ini mencakup tahap-tahap: (1) perencanaan, (2) pelaksanaan, (3) pengamatan, dan (4) refleksi. Keempat kegiatan tersebut saling terkait dan secara urut membentuk sebuah siklus. Penelitian Tindakan Sekolah merupakan penelitian yang bersiklus, artinya penelitian dilakukan secara berulang dan berkelanjutan sampai tujuan penelitian dapat tercapai.

Alur PTKp dapat dilihat pada gambar berikut :

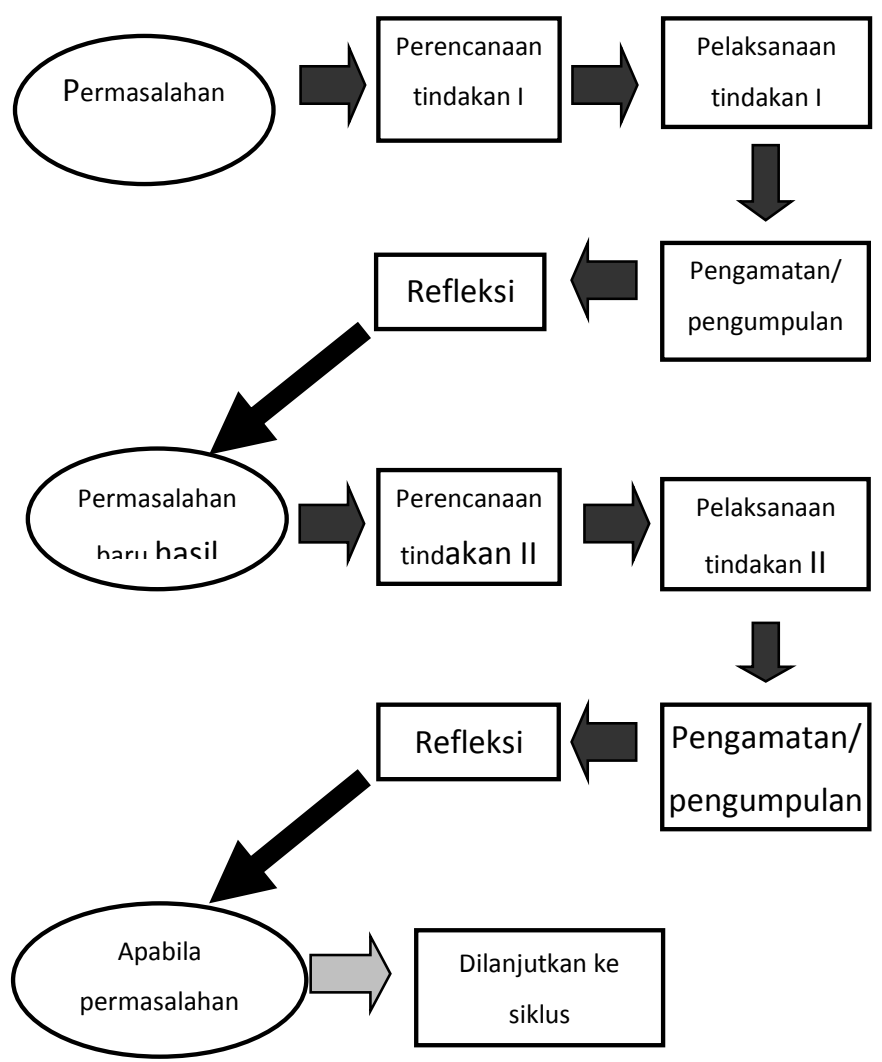

Rencana pelaksanaan dilakukan dalam dua siklus yaitu

1. Pelaksanaan Tindakan Siklus 1

Perencanaan tindakan siklus 1 memiliki tahapan sebagai berikut:

A. Tahap Perencanaan

Pada tahap perencanaan kegiatan yang dilakukan adalah merencanakan pelaksanaan workshop, membuat skenario workshop, menyiapkan media, membuat lembar observasi untuk pengamat serta membuat instrument penilaian. 
B. Tahap Pelaksanaan

Pelaksanaan workshop pada siklus 1 yaitu tanggal 14 Agustus 2017. Kegiatan dilaksanakan mulai pukul 08.00 - 15.00. Untuk menjelaskan cara membuat PTK digunakan ceramah yang diselingi dengan tanya jawab agar terjadi interaksi antara peserta dengan peneliti sedangkan tugas akhir digunakan untuk mengukur ketercapaian indikator dari peserta Adapun pelaksanaan siklus 1 dengan skenario sebagai berikut: Pembukaan Workshop oleh Kepala Madrasah; Sambutan dari pengawas pembina sebagai peneliti juga observer; Peneliti menyampaikan tujuan diadakannya Workshop; Penyampaian materi PTK oleh narasumber dari Balai Diklat Kementerian Agama Provinsi DKI yaitu Bapak DR. Juanda Kasim, M.Si.

Adapun indikator keberhasilannya adalah diharapkan guru dapat menetapkan judul proposal PTK, membuat latar belakang masalah, membuat rumusan masalah, menentukan pemecahan masalah, menentukan tujuan penelitian, menentukan manfaat penelitian, merumuskan kajian teori, menentukan metode penelitian, tanya jawab, penyelesaian tugas serta tugas membuat proposal PTK yang dikerjakan di Rumah.

C. Tahap Pengamatan

Pengamatan dilakukan oleh peneliti/observer untuk melihat keaktifan peserta dan proses pelaksanaan Workshop.

D. Tahap Refleksi

Dalam refleksi ini ada banyak hal yang harus dilakukan, yaitu mulai dari mengevaluasi tindakan sampai dengan memutuskan apakah masalah itu tuntas atau perlu tindakan lain dalam siklus berikutnya.

Kegiatan dalam refleksi antara lain merenungkan kembali mengenai kekuatan dan kelemahan dari tindakan yang telah dilakukan, menjawab tentang penyebab situasi dan kondisi yang terjadi selama pelaksanaan tindakan, serta memperkirakan solusi yang akan digunakan.

Hasil yang diperoleh dari tugas akhir peserta (guru) dan tingkat keaktifan peserta serta penilaian proses pelaksanaan Workshop akan dianalisis. Apabila terdapat peserta yang belum mencapai indikator keberhasilan maka akan dicari kelemahan-kelemahan yang sudah dilakukan pada siklus 1 . Untuk perbaikannya agar indikator tercapai akan dilakukan penelitian lanjutan yaitu siklus 2 .

\section{Pelaksanaan Tindakan Siklus 2}

Perencanaan tindakan siklus 2 memiliki tahapan sebagai berikut: 


\section{A. Tahap Perencanaan}

Pada tahap perencanaan kegiatan yang dilakukan adalah merencanakan pelaksanaan workshop, membuat skenario workshop, menyiapkan media, menyiapkan lembar observasi untuk pengamatan, serta menyiapkan instrumen penilaian.

B. Tahap Pelaksanaan

Pelaksanaan Workshop pada siklus 2 adalah tanggal 23 Agustus 2017. Kegiatan ceramah masih dilakukan hanya lebih dioptimalkan terutama pada aspek-aspek yang belum mencapai standar. Selain itu ditambahkan dengan kegiatan diskusi kelompok, dimana peserta dibagi dalam 3 kelompok, setiap kelompok terdiri dari peserta yang sudah mencapai indikator keberhasilan dan yang belum hal ini dimaksudkan agar terjadi transfer dari peserta yang sudah bisa dan yang belum bisa.

Kegiatan dilaksanakan pukul 09.00 - 15.00 dengan rincian pelaksanaan kegiatannya adalah sebagai berikut pembukaan workshop oleh kepala madrasah, peneliti menyampaikan motivasi, narasumber menyampaikan materi PTK, narasumber bertanya tentang PR membuat proposal PTK kepada guru, narasumber memeriksa dan mengoreksi satu persatu proposal PTK yang dibuat oleh guru, tanya jawab, diskusi antara narasumber dan guru, serta narasumber memberikan tugas kepada guru untuk memperbaiki proposal PTK yang sudah dikoreksi oleh narasumber.

C. Tahap Pengamatan

Pengamatan dilakukan oleh peneliti/observer untuk melihat keaktifan peserta dan proses pelaksanaan Workshop.

D. Tahap Refleksi

Dalam refleksi ini ada banyak hal yang harus dilakukan, yaitu mulai dari mengevaluasi tindakan sampai dengan memutuskan apakah masalah itu tuntas atau perlu tindakan lain dalam siklus berikutnya. Kegiatan dalam refleksi antara lain merenungkan kembali mengenai kekuatan dan kelemahan dari tindakan yang telah dilakukan, menjawab tentang penyebab situasi dan kondisi yang terjadi selama pelaksanaan tindakan, serta memperkirakan solusi yang akan digunakan.

Hasil yang dipertoleh dari tugas akhir peserta (guru) dan tingkat keaktifan peserta serta penilaian proses pelaksanaan Workshop akan dianalisis. Apabila terdapat peserta yang belum mencapai indikator keberhasilan maka akan dicari kelemahan-kelemahan yang sudah dilakukan pada siklus 2. Apabila pada siklus ini hasilnya belum mencapai 
indikator yang ditetapkan maka akan dilanjutkan pada siklus berikutnya. Apabila sudah mencapai maka tidak perlu lagi diadakan tindakan untuk perbaikan .

\section{ANALISA DATA}

Data yang telah dikumpulkan kemudian dianalisis, dengan menggunakan analisis kualitatif dan kuantitatif. Analisa kualitatif untuk mengetahui sejauh mana keaktifan guru dalam proses workshop. Adapun analisa kuantitatif digunakan untuk mengetahui nilai kompetensi guru binaan dalam membuat proposal Penelitian Tindakan Kelas (PTK) dengan tingkat ketercapaian sebagai berikut:

Sangat baik 91-100\% ; Baik 76-90 \% ; Sedang 61-75\% ; Kurang baik 51-60 \% , dan ; Tidak baik $\leq 50 \%$

\section{HASIL DAN PEMBAHASAN}

\section{Deskripsi Hasil Pelaksanaan Tindakan Siklus 1}

Siklus 1 dilakukan pada hari Senin, 14 Agustus 2017. Aspek yang dinilai adalah kemampuan menetapkan judul proposal PTK, kemampuan menentukan latar belakang masalah, kemampuan membuat rumusan masalah, kemampuan menentukan pemecahan masalah, kemampuan menentukan tujuan PTK, kemampuan menentukan manfaat PTK, kemampuan merumuskan kajian teori, kemampuan menentukan metode penelitian serta tingkat keaktifan peserta.

Dari penelitian tindakan siklus 1 diperoleh hasil sebagai berikut :

1. Kemampuan peserta dalam menentukan PTK yang mencapai standar yakni hanya $65,4 \%$, belum mencapai harapan dari $80 \%$ yang diharapkan. Hal ini ditunjukkan bahwa :
a) Kemampuan menetapkan Judul PTK 61,5\%,
b) Kemampuan membuat Latar Belakang Masaah 23,1\%,
c) Kemampuan membuat Rumusan Masalah 69,2\%,
d) Kemampuan menentukan Pemecahan Masalah 6,1\%,
e) Kemampuan menentukan Tujuan PTK 38,5\%,
f) Kemampuan menentukan Manfaat PTK 84,6\%,
g) Kemampuan Merumuskan Kajian Teori 100\%,
h) Kemampuan Menentukan Metode Penelitian 100\%. 
2. Tingkat keaktifan peserta masih kurang. Hal ini ditunjukkan bahwa :

a) Peserta yang aktif hanya $23,1 \%$,

b) Peserta yang tidak aktif mencapai $76,9 \%$.

3. Metode yang digunakaan peneliti belum optimal. Hal ini ditunjukkan bahwa :

a) Ceramah belum baik, yakni terlalu umum,

b) Tanya jawab belum baik.

Untuk mengatasi masalah tersebut perlu dilaksanakan lagi tindakan pada silkus 2. Pada siklus 2, ceramah masih perlu dilakukan dengan lebih spesifik, dengan cara menekankan pada aspek-aspek yang belum memenuhi standar. Tanya jawab agar menjadi amat baik dengan cara diwajibkan setiap peserta untuk bertanya. Untuk meningkatkan tingkat keaktifan peserta perlu ditambahkan metode diskusi kelompok. Teknis pelaksanaan diskusi kelompok yaitu peserta akan dibagi menjadi 3 kelompok. Tiap kelompok terdiri dari peserta yang sudah memenuhi standar dan yang belum memenuhi standar, agar terjadi transfer pengalaman dari peserta yang sudah memenuhi standar ke yang belum memenuhi standar. Dengan keadaan ini peneliti mempunyai keyakinan pada siklus 2 ini kemampuan peserta dalam menetapkan PTK akan terjadi peningkatan.

\section{Deskripsi Hasil Pelaksanaan Tindakan Siklus 2}

Siklus 2 dilaksanakan pada hari Rabu, 23 Agustus 2017. Aspek yang dinilai adalah kemampuan menetapkan judul proposal PTK, kemampuan menentukan latar belakang masalah, kemampuan membuat rumusan masalah, kemampuan menentukan pemecahan masalah, kemampuan menentukan tujuan PTK, kemampuan menentukan manfaat PTK, kemampuan merumuskan kajian teori, kemampuan menentukan metode penelitian serta tingkat keaktifan peserta.

Dari penelitian tindakan siklus 2 diperoleh hasil sebgai berikut :

1. Kemampuan peserta dalam membuat PTK sudah mencapai standar yakni $96,2 \%$, bahkan melampaui dari $80 \%$ yang diharapkan. Hal ini ditunjukan bahwa :
a) Kemampuan menetapkan Judul PTK 100\%,
b) Kemampuan membuat Latar Belakang Masalah 84,6\%,
c) Kemampuan membuat Rumusan Masalah 92,3\%,
d) Kemampuan menentukan Pemecahan Masalah 100\%,
e) Kemampuan menentukan tujuan PTK 92,3\%,
f) Kemampuan menentukan Manfaat PTK 100\%, 
g) Kemampuan merumuskan Kajian Teori 100\%,

h) Kemampuan menentukan Metode Penelitian 100\%.

2. Tingkat Keaktifan peserta sudah baik. Hal ini ditunjukkan bahwa :

a) Peserta yang aktif $34,8 \%$,

b) Peserta yang sangat aktif $30,8 \%$.

3. Metode yang digunakan peneliti sudah optimal. Hal ini ditunjukkan bahwa :

a) Ceramah sudah baik, yakni lebih spesifiik,

b) Tanya jawab sudah baik.

Dari hasil tindakan pelaksanaan siklus 2 ini upaya meningkatkan kemampuan guru untuk menetapkan PTK, mengalami peningkatan dari siklus 1. Hal ini dapat dilihat dari peserta yang sudah memenuhi standar maupun hasil pengamatan dari peneliti/observer tentang keaktifan peserta dan keadaan pelaksanaan Workshop. Pada siklus 2, setelah ditambahkan diskusi kelompok terjadi peningkatan baik kemampuan peserta membuat PTK maupun keaktifan mereka bila dibandingkan dengan siklus 1 .

\section{Perbandingan Hasil Pelaksanaan Workshop antara Siklus 1 dan Siklus 2}

Pada siklus I aspek membuat PTK yang sudah memenuhi atau mencapai standar adalah Kemampuan Menetapkan Judul PTK 61,5\%, Kemampuan Membuat Latar Belakang Masalah 23,1\%, Kemampuan Membuat Rumusan Masalah 69,2\%, Kemampuan Menentukan Pemecahan Masalah 46,1\%, Kemampuan Menentukan Tujuan PTK 38,5\%, Kemampuan Menetapkan Manfaat PTK 84,6\%, Kemampuan Merumuskan Kajian Teori 100\%, Kemampuan Menentukan Hipotesis Tindakan 100\%. Sedangkan pada siklus II aspek membuat PTK yang sudah memenuhi standar adalah Kemampuan Menetapkan Judul PTK 100\%, Kemampuan Membuat Latar Belakang Masalah 84,6\%, Kemampuan Membuat Rumusan Masalah 92,3\%, Kemampuan Menentukan Pemecahan Masalah 100\%, Kemampuan Menentukan Tujuan PTK 92,3\%, Kemampuan Menentukan Manfaat PTK 100\%, Kemampuan Merumuskan Kajian Teori 100\%, Kemampuan Menentukan Metode Penelitian 100\%. Perbandingan setiap aspek PTK pada siklus 1 dan 2 bisa dilihat pada grafik 1. 
Grafik 1. Perbandingan Tiap Aspek PTK yang sudah memenuhi standar antara siklus 1 dan 2

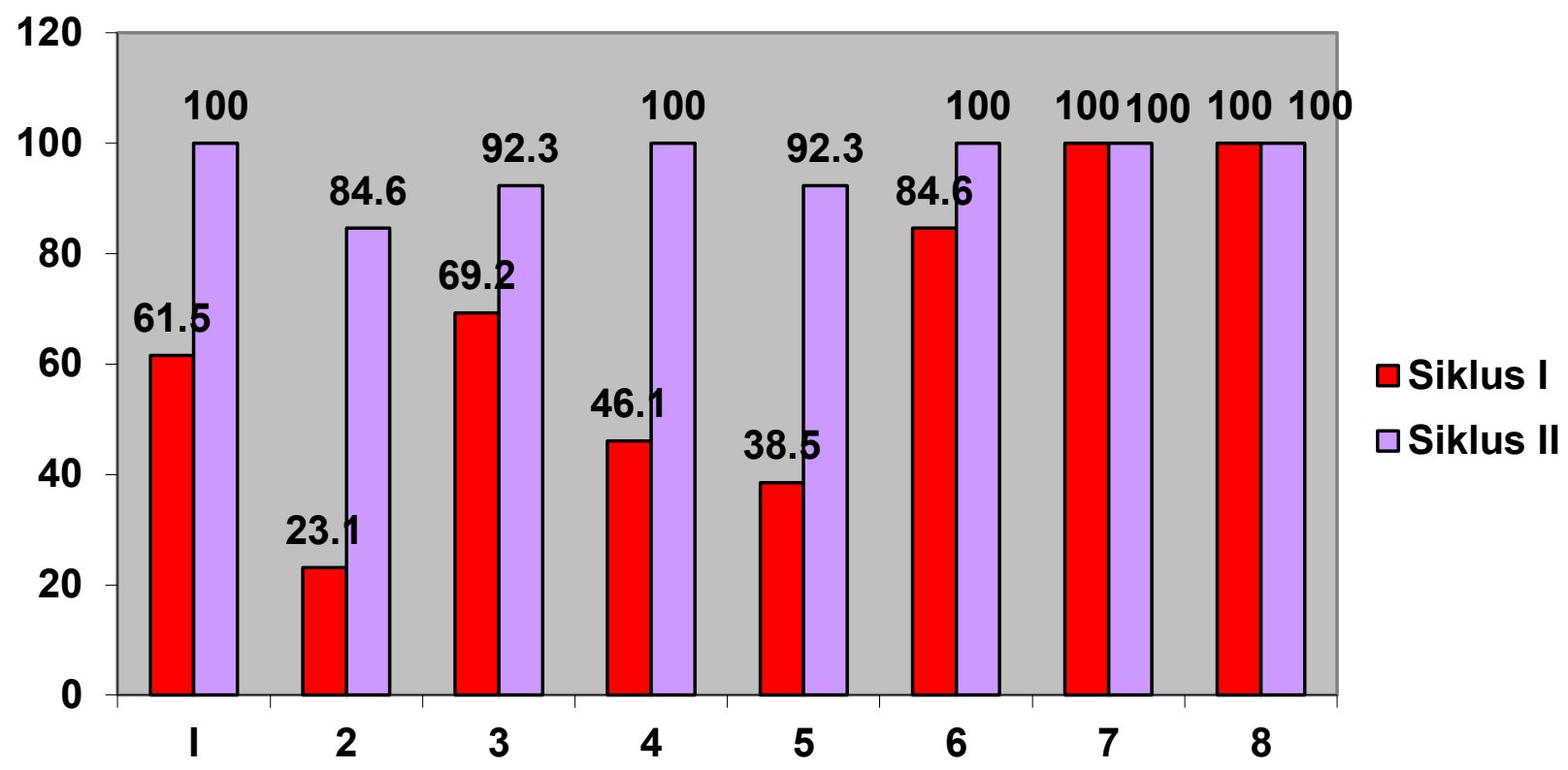

Keterangan :

$1=$ Kemampuan Menetapkan Judul PTK

$2=$ Kemampuan Membuat Latar Belakang Masalah

3 = Kemampuan Membuat Rumusan Masalah

$4=$ Kemampu an Menentukan Pemecahan Masalah

5 = Kemampuan Menentukan Tujuan PTK

6 = Kemampuan Menentukan Manfaat PTK

7 = Kemampuan Merumuskan Kajian Teori

8 = Kemampuan Menentukan Metode Penelitian

Sedangkan rata-rata setiap aspek PTK yang sudah memenuhi standar pada siklus 1 $(65,4 \%)$ dan pada siklus 2 (96,1\%). Perbandingan rata-rata setiap aspek PTK yang sudah memenuhi standar pada siklus 1 dan 2 bisa dilihat pada grafik 2 . 
Grafik 2. Perbandingan Rata-Rata Aspek PTK yang Sudah Memenuhi Standar Antara Siklus 1

$(65,4 \%)$ dan Siklus $2(96,1 \%)$

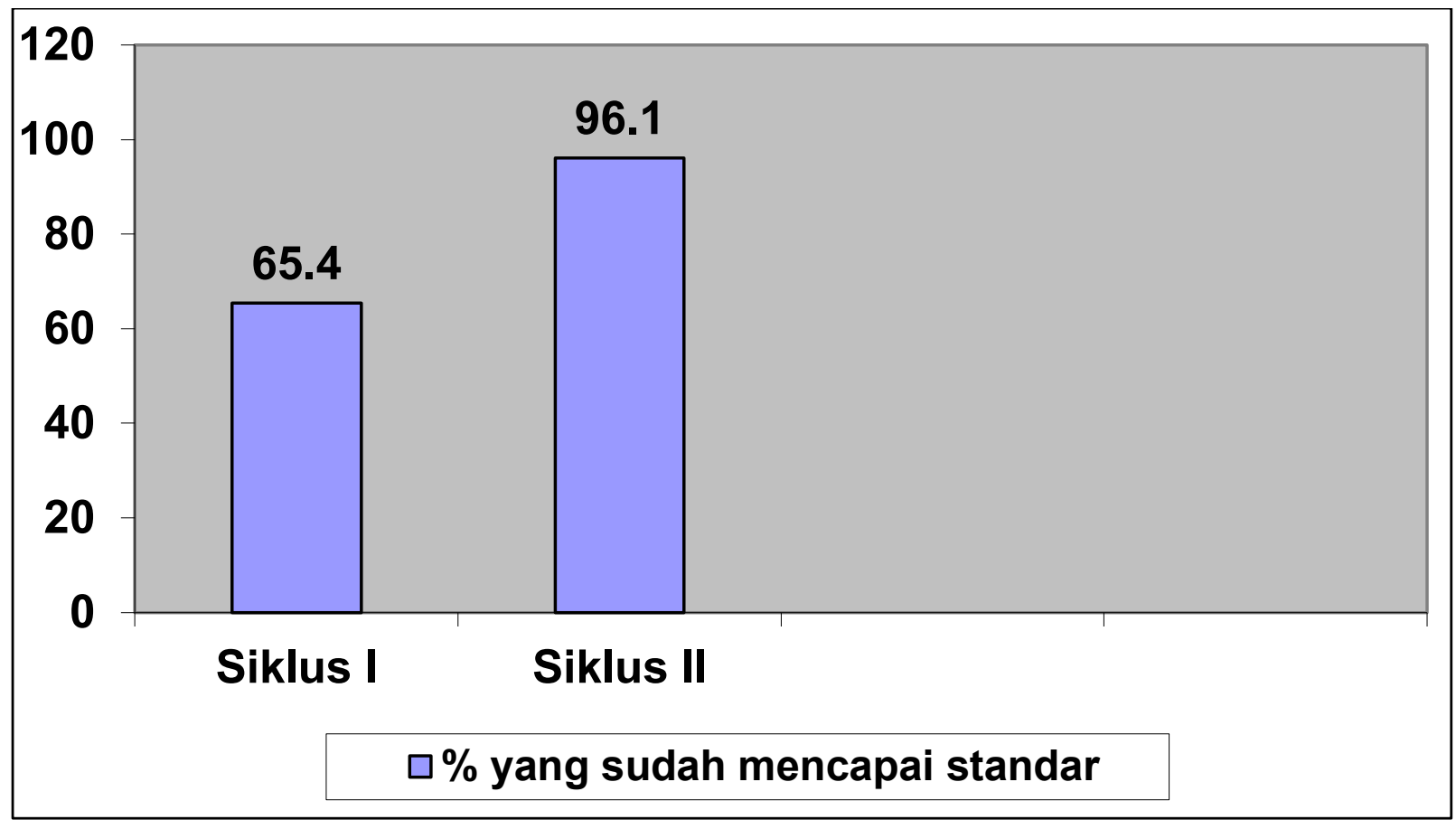

Pada siklus 1 peserta yang kurang aktif 11 orang ( 46,2\%), cukup aktif sebanyak 8 orang $(30,8 \%)$, dan yang aktif sebanyak 6 orang $(23,1 \%)$. Jadi pada siklus 1 peserta yang aktif hanya 6 orang $(23,1 \%)$. Sedangkan pada siklus 2 peserta yang cukup aktif 8 orang $(30,8 \%)$, peserta yang aktif sebanyak 9 orang (38,5\%) dan peserta yang sangat aktif sebanyak 8 orang (30,8\%). Jadi pada siklus 2 ini peserta yang aktif sebanyak 17 orang $(69,2 \%)$. Dengan demikian pada siklus 2 ini terjadi peningkatan pada keaktifan peserta sebesar $46,2 \%$ atau sebanyak 11 orang. Untuk lebih jelasnya bisa dilihat pada grafik dibawah ini 
Grafik 3. Perbandingan Tingkat Keaktifan Peserta Workshop Antara Siklus 1 dan Siklus 2

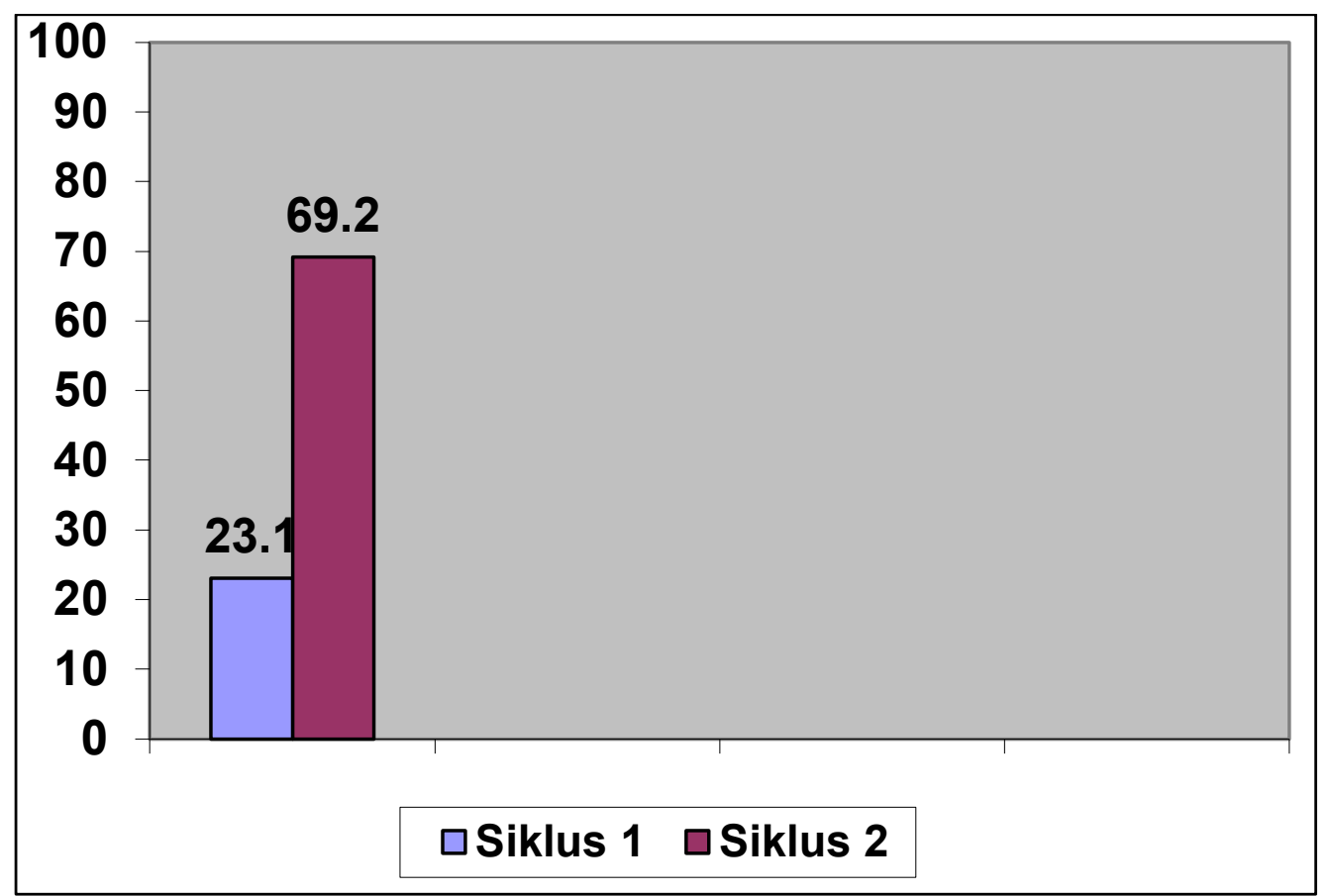

\section{KESIMPULAN}

Data yang diperoleh di lapangan ternyata benar bahwa untuk meningkatkan kompetensi guru dalam membuat Proposal Penelitian Tindakan Kelas (PTK) dapat dilakukan dengan kegiatan workshop. Maka dapat disimpulkan bahwa kegiatan workshop terbukti dapat meningkatkan keaktifan guru dalam menyusun proposal PTK di Madrasah Tsanawiyah Binaan Kota Jakarta Selatan. Hal ini terbukti dengan nilai aktifitas guru di Madrasah Tsanawiyah Binaan meningkat dari rata-rata pada Siklus I sebesar 65,4\% menjadi 96,1\% pada Siklus II; dan kegiatan workshop terbukti dapat meningkatkan kompetensi guru dalam membuat PTK di Madrasah Tsanawiyah Binaan Kota Jakarta Selatan. 


\section{DAFTAR PUSTAKA}

Agus Kristiyanto. 2010. Penelitian Tindakan Kelas Dalam Pendidikan Jasmani dan Kepelatihan Olahraga. Surakarta: UNS Press.

Arikunto Suharsimi. 2006. Penelitian Tindakan Kelas. Jakarta: Bina Aksara.

Badudu, J.S. 1988. Kamus Besar Bahasa Indonesia. Jakarta : Gramedia.

Danim, Sudarwan. 2002. Menjadi Peneliti Kualitatif. Bandung: CV Pustaka Setia.

Departemen Pendidikan Nasional Badan Penelitian dan Pengembangan Pusat Kurikulum. 2008. Bahan Bantuan Teknis PTK dan Workshop Pengembangan Kurikulum. Jakarta.

Emzir. 2007. Metodologi Penelitian Pendidikan Kuantitatif dan Kualitatif. Raja Grafindo Persada : Jakarta.

Iskandar. 2012. Penelitian Tindakan Kelas. Jakarta. REFERENSI (GP Press Group).

Lestari, Tita. 2000. Merencanakan dan Melaksanakan Penelitian Tindakan Sekolah. Disampaikan pada Kegiatan Pembekalan Pembimbing Penelitian Tindakan Sekolah di Bogor.

Mulyasa. 2011. Praktik Penelitian Tindakan Kelas. Bandung: PT. Remaja Rosdakarya. 